NASA/TM-2002-211695

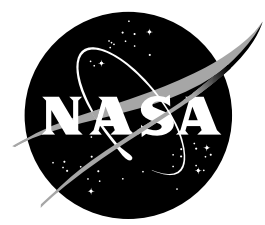

\title{
Electronics for Deep Space Cryogenic Applications
}

R.L. Patterson

Glenn Research Center, Cleveland, Ohio

A. Hammoud

QSS Group, Inc., Cleveland, Ohio

J.E. Dickman

Glenn Research Center, Cleveland, Ohio

S.S. Gerber

ZIN Technologies, Inc., Brook Park, Ohio

M.E. Elbuluk

University of Akron, Akron, Ohio

E. Overton

Glenn Research Center, Cleveland, Ohio 
Since its founding, NASA has been dedicated to the advancement of aeronautics and space science. The NASA Scientific and Technical Information (STI) Program Office plays a key part in helping NASA maintain this important role.

The NASA STI Program Office is operated by Langley Research Center, the Lead Center for NASA's scientific and technical information. The NASA STI Program Office provides access to the NASA STI Database, the largest collection of aeronautical and space science STI in the world. The Program Office is also NASA's institutional mechanism for disseminating the results of its research and development activities. These results are published by NASA in the NASA STI Report Series, which includes the following report types:

- $\quad$ TECHNICAL PUBLICATION. Reports of completed research or a major significant phase of research that present the results of NASA programs and include extensive data or theoretical analysis. Includes compilations of significant scientific and technical data and information deemed to be of continuing reference value. NASA's counterpart of peerreviewed formal professional papers but has less stringent limitations on manuscript length and extent of graphic presentations.

- TECHNICAL MEMORANDUM. Scientific and technical findings that are preliminary or of specialized interest, e.g., quick release reports, working papers, and bibliographies that contain minimal annotation. Does not contain extensive analysis.

- CONTRACTOR REPORT. Scientific and technical findings by NASA-sponsored contractors and grantees.
- CONFERENCE PUBLICATION. Collected papers from scientific and technical conferences, symposia, seminars, or other meetings sponsored or cosponsored by NASA.

- SPECIAL PUBLICATION. Scientific, technical, or historical information from NASA programs, projects, and missions, often concerned with subjects having substantial public interest.

- TECHNICAL TRANSLATION. Englishlanguage translations of foreign scientific and technical material pertinent to NASA's mission.

Specialized services that complement the STI Program Office's diverse offerings include creating custom thesauri, building customized databases, organizing and publishing research results ... even providing videos.

For more information about the NASA STI Program Office, see the following:

- Access the NASA STI Program Home Page at http://www.sti.nasa.gov

- E-mail your question via the Internet to help@sti.nasa.gov

- Fax your question to the NASA Access Help Desk at 301-621-0134

- Telephone the NASA Access Help Desk at 301-621-0390

- Write to:

NASA Access Help Desk

NASA Center for AeroSpace Information 7121 Standard Drive

Hanover, MD 21076 
NASA/TM-2002-211695

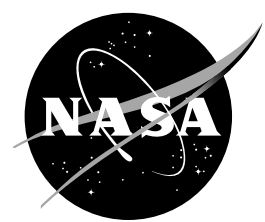

\section{Electronics for Deep Space Cryogenic Applications}

\section{R.L. Patterson}

Glenn Research Center, Cleveland, Ohio

A. Hammoud

QSS Group, Inc., Cleveland, Ohio

J.E. Dickman

Glenn Research Center, Cleveland, Ohio

S.S. Gerber

ZIN Technologies, Inc., Brook Park, Ohio

M.E. Elbuluk

University of Akron, Akron, Ohio

E. Overton

Glenn Research Center, Cleveland, Ohio

Prepared for the

Fifth European Workshop on Low Temperature Electronics

sponsored by the Institut National Polytechnique de Grenoble

Grenoble, France, June 19-21, 2002

National Aeronautics and

Space Administration

Glenn Research Center 
Available from

NASA Center for Aerospace Information 7121 Standard Drive

Hanover, MD 21076
National Technical Information Service 5285 Port Royal Road Springfield, VA 22100

Available electronically at http://gltrs.grc.nasa.gov 


\title{
ELECTRONICS FOR DEEP SPACE CRYOGENIC APPLICATIONS
}

\author{
R.L. Patterson \\ National Aeronautics and Space Administration \\ Glenn Research Center \\ Cleveland, Ohio 44135 \\ A. Hammoud \\ QSS Group, Inc. \\ Cleveland, Ohio 44135 \\ J.E. Dickman \\ National Aeronautics and Space Administration \\ Glenn Research Center \\ Cleveland, Ohio 44135 \\ S. Gerber \\ ZIN Technologies, Inc. \\ Brook Park, Ohio 44142 \\ M.E. Elbuluk \\ University of Akron \\ Akron, Ohio 44325 \\ E. Overton \\ National Aeronautics and Space Administration \\ Glenn Research Center \\ Cleveland, Ohio 44135
}

\begin{abstract}
Deep space probes and planetary exploration missions require electrical power management and control systems that are capable of efficient and reliable operation in very cold temperature environments. Typically, in deep space probes, heating elements are used to keep the spacecraft electronics near room temperature. The utilization of power electronics designed for and operated at low temperature will contribute to increasing efficiency and improving reliability of space power systems. At NASA Glenn Research Center, commercial-off-the-shelf devices as well as developed components are being investigated for potential use at low temperatures. These devices include semiconductor switching devices, magnetics, and capacitors. Integrated circuits such as digital-to-analog and analog-to-digital converters, DC/DC converters, operational amplifiers, and oscillators are also being evaluated. In this paper, results will be presented for selected analog-to-digital converters, oscillators, DC/DC converters, and pulse width modulation (PWM) controllers.
\end{abstract}

\section{INTRODUCTION}

Planetary exploration missions and deep space probes require electrical power management and control systems that are capable of efficient and reliable operation in very low temperature environments. Presently, spacecraft operating in the cold environment of deep space carry a large number of radioisotope heating units in order to maintain the surrounding temperature of the on-board electronics at approximately $20^{\circ} \mathrm{C}$. 
In addition to deep space applications, low temperature electronics have potential uses in terrestrial applications that include magnetic levitation transportation systems, medical diagnostics, cryogenic instrumentation, and super-conducting magnetic energy storage systems. The utilization of power electronics designed for and operated at low temperature is expected to result in more efficient systems than room temperature systems. This improvement results from better electronic, electrical, and thermal properties of materials at low temperatures [1-3]. In particular, the performance of certain semiconductor devices improves with decreasing temperature down to liquid nitrogen temperature $\left(-196^{\circ} \mathrm{C}\right)[3,4]$. At low temperatures, majority carrier devices demonstrate reduced leakage current and reduced latch-up susceptibility. In addition, these devices show higher speed resulting from increased carrier mobility and saturation velocity [3-5]. An example is the power MOSFET that has lower conduction losses at low temperature due to the reduction in the drain-to-source resistance RDS(on) resulting from increased carrier mobility $[4,6,7]$.

\section{NASA GLENN RESEARCH CENTER LOW TEMPERATURE ELECTRONICS PROGRAM}

The Low Temperature Electronics Program at the NASA Glenn Research Center (GRC) focuses on research and development of electrical components and systems suitable for applications in deep space missions. Research is being conducted on devices and systems for use down to cryogenic temperature $\left(-196^{\circ} \mathrm{C}\right)$. The goal of the low temperature electronics program is to develop and demonstrate reliable, efficient, power systems capable of surviving and exploiting the advantages of low temperature environments. The targeted systems are mission-driven and include converters, inverters, controls, digital circuits, and special-purpose circuits. Initial development efforts have produced the successful demonstration of low temperature operation and cold-restart of several DC/DC converters (with outputs from 5 to 1000 Watts) utilizing different design topologies $[1,4,7]$. Some of these circuits employed superconducting inductors.

In support of system development, device and component research and development efforts are underway in critical areas of passive and active components, optoelectronic devices, and energy generation and storage. Initially, commercial-off-the-shelf (COTS) devices and components are characterized in terms of their performance at low-temperatures. When viable commercial devices fail to meet mission requirements, efforts are then undertaken to develop advanced components.

\section{LOW TEMPERATURE R\&D ACTIVITIES}

\subsection{Analog-to-Digital Converters}

A commercial off-the-shelf 12-bit serial CMOS analog-to-digital converter, which was rated for operation between $-40{ }^{\circ} \mathrm{C}$ and $+85{ }^{\circ} \mathrm{C}$, was evaluated from room temperature to $-190{ }^{\circ} \mathrm{C}$ in a liquid nitrogen cooled chamber. Parameters investigated included voltage conversion and control signal timing at a switching frequency of $100 \mathrm{kHz}$. Although the device had a built-in internal voltage reference, tests were also carried out using an external voltage reference. In either case, the device was able to provide the voltage conversions throughout the entire test temperature range down to $-190{ }^{\circ} \mathrm{C}$. The converted output obtained using an external voltage reference, however, was more accurate than those obtained with an internal voltage reference. Results obtained at three different temperatures with an external reference are shown in Table 1. 


\subsection{Oscillators}

A number of oscillators were designed and evaluated for low temperature operation. Figure 1 shows normalized frequency for an uncompensated silicon FET oscillator, an uncompensated oscillator designed for ultra low temperature, and a compensated oscillator modified for low temperature operation. It can be seen clearly that only the compensated modified oscillator was able to hold frequency, namely within $+/-0.3$ parts per million from $+85^{\circ} \mathrm{C}$ down to $-189^{\circ} \mathrm{C}$.

\subsection{DC/DC Converters}

Several DC/DC converters have been built and characterized, in-house, at low temperatures. The converters were designed or modified to operate from room temperature to $-196^{\circ} \mathrm{C}$ using commercially available components such as CMOS-type devices and MOSFET switches. These systems had output power range from $5 \mathrm{~W}$ to $1 \mathrm{~kW}$ with switching frequencies of $50 \mathrm{kHz}$ to $200 \mathrm{kHz}$. Pulse width modulation technique was implemented in most of these systems with open-loop as well as closed-loop control. The topologies included buck, boost, multi-resonant, push-pull and full-bridge configuration [8-11].

In addition, several commercially available $\mathrm{DC} / \mathrm{DC}$ converter modules were investigated for potential use at low temperatures. For example, the output voltage of a commercial DC/DC converter at various load levels is shown as a function of temperature in Figure 2. It can be seen that the output voltage of this particular module tends to be steady only between $+20{ }^{\circ} \mathrm{C}$ and $-20{ }^{\circ} \mathrm{C}$. A slight reduction occurs in voltage regulation as temperature is further decreased to $-80{ }^{\circ} \mathrm{C}$. Beyond that temperature, the converter tends to become unstable in terms of voltage regulation. This behavior occurs regardless of the levels of the applied input voltage and connected output load.

Another commercial DC/DC module included in this investigation faired relatively well in terms of its output regulation with temperature. The output voltage of this converter is depicted in Figure 3 as a function of temperature at various load levels.

\subsection{PWM Controllers}

Current-mode and voltage-mode pulse width modulation controllers were evaluated extensively for low temperature operation. The performance of one of those commercial grade pulse width modulation controller chips was evaluated between $25^{\circ} \mathrm{C}$ and $-190^{\circ} \mathrm{C}$. The device displayed acceptable performance throughout the entire test temperature range. Waveforms of the device reference voltage, oscillator, and output switching voltage, which were recorded at a control voltage (VC) of $1.5 \mathrm{~V}$, are shown in Figures 4 and 5 at test temperature of $25^{\circ} \mathrm{C}$ and $-190{ }^{\circ} \mathrm{C}$, respectively. It can be seen clearly that all investigated properties did not undergo much change with temperature, as evident from the similarity of the waveforms shown for both extreme temperature, i.e., $25^{\circ} \mathrm{C}$ and $-190{ }^{\circ} \mathrm{C}$.

\section{CONCLUSION}

The research efforts are focused on developing selected, mission-driven, power systems and supporting technologies for low temperature operation. The on-going low temperature activities include dielectric research and evaluation, power component development, and electronic system integration and demonstration. Other research investigations comprise long-term reliability assessment of power devices and integrated circuits and the effects of low temperature exposure on device interconnect and packaging. 


\section{REFERENCES}

1. Gerber, S.S., Patterson, R.L., Ray, B., and Stell, C., "Performance of a spacecraft DC/DC converter breadboard modified for low temperature operation," IECEC 96, 1, pp. 592-598.

2. Kirschman, R.K., "Low temperature electronic device operation," Symp. Electrochemical Society, (1991), 14.

3. Dean, M., Foty D., Saks, N., Raider, S., and Oleszel, G., "Low temperature microelectronics: opportunities and challenges," Proc. Symp. Low Temperature Electronic Device Operation, Electrochemical Society, (1991), 14, pp. 25-37.

4. Ray, B., Gerber, S.S., Patterson, R.L., and Myers, I.T., "Power control electronics for cryogenic instrumentation," Advances in Inst. and Control, (1995), 50, 1, Int. Soc. for Measurement and Control, pp. 131-139.

5. Kirshman, R.K., "Cold electronics: an overview," Cryogenics, (1985), 25, 3, pp. 115-122.

6. Mueller, O., "On-resistance, thermal resistance and reverse recovery time of power MOSFETs at 77K," Cryogenics, (1989), 29, pp. 1006-1014.

7. Ray, B., Gerber, S.S., Patterson, R.L., and Myers, I.T., "77K Operation of a multi-resonant power converter," IEEE PESC'95 Record, (1995), 1, pp. 55-60.

8. Ray, B., Gerber, S.S., and Patterson, R.L., "Low temperature performance of a full-bridge DC/DC converter," IECEC 96, 1, pp. 553-559.

9. Ray, B., Gerber, S.S., Patterson, R.L., and Myers, I.T., "Liquid nitrogen temperature operation of a switching power converter," Symp. on Low Temp. Electronics and High Temperature Superconductivity, (1995), 9, pp. 345-352.

10. Gerber, S.S., Miller, T., Patterson, R.L., and Hammoud, A., "Performance of a closed-loop controlled high voltage DC/DC converter at cryogenic temperature," IECEC 98, 1, pp. 1083-1092.

11. Ray, B. and Patterson, R.L., "Wide temperature operation of a PWM DC/DC converter," IEEE Industry Applications Society Conference, (1995), pp. 971-976.

Table 1. Converted output voltage at various temperatures.

\begin{tabular}{|c|c|c|c|}
\hline $\begin{array}{c}\text { Input } \\
(\mathrm{V})\end{array}$ & $\begin{array}{c}\text { Output } \\
@, 25^{\circ} \mathrm{C}\end{array}$ & $\begin{array}{c}\text { Output } \\
\left(a-100{ }^{\circ} \mathrm{C}\right.\end{array}$ & $\begin{array}{c}\text { Output } \\
@-190{ }^{\circ} \mathrm{C}\end{array}$ \\
\hline 0 & 0.007 & 0.010 & 0.010 \\
\hline 0.5 & 0.505 & 0.498 & 0.508 \\
\hline 1 & 1.004 & 1.006 & 1.004 \\
\hline 2 & 2.000 & 2.002 & 1.993 \\
\hline 5 & 4.994 & 4.994 & 5.001 \\
\hline 7.25 & 7.241 & 7.228 & 7.226 \\
\hline 10 & 9.983 & 9.963 & 9.963 \\
\hline 10.1 & 10.000 & 10.000 & 10.000 \\
\hline
\end{tabular}

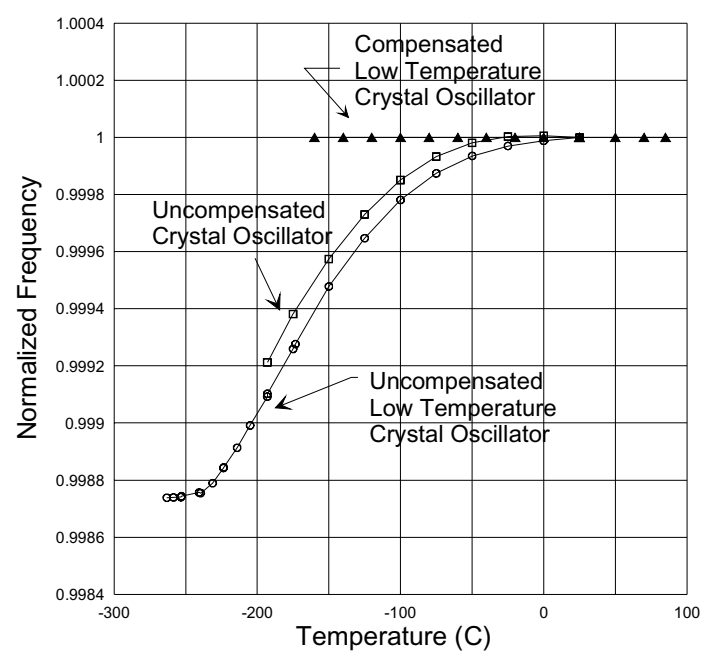

Figure 1. Normalized frequency output for three types of oscillators. 


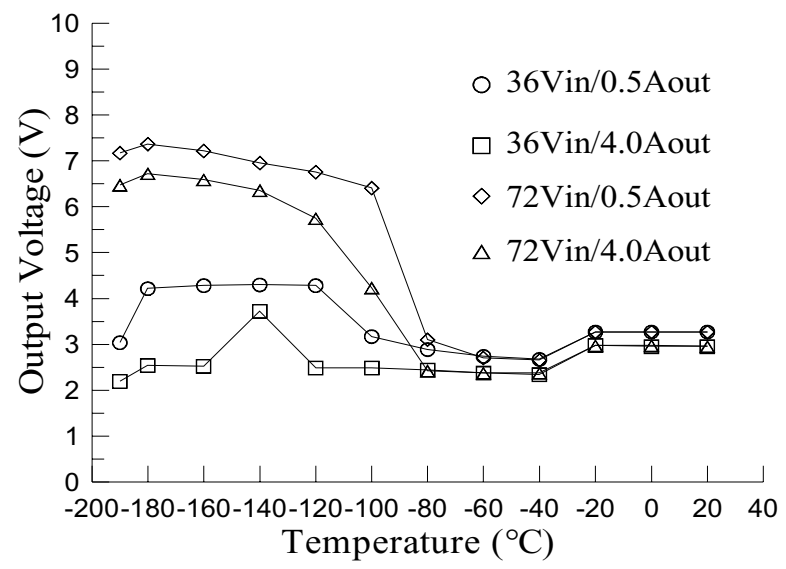

Figure 2. Poor performance of one commercial $\mathrm{dc} / \mathrm{dc}$ converter module.
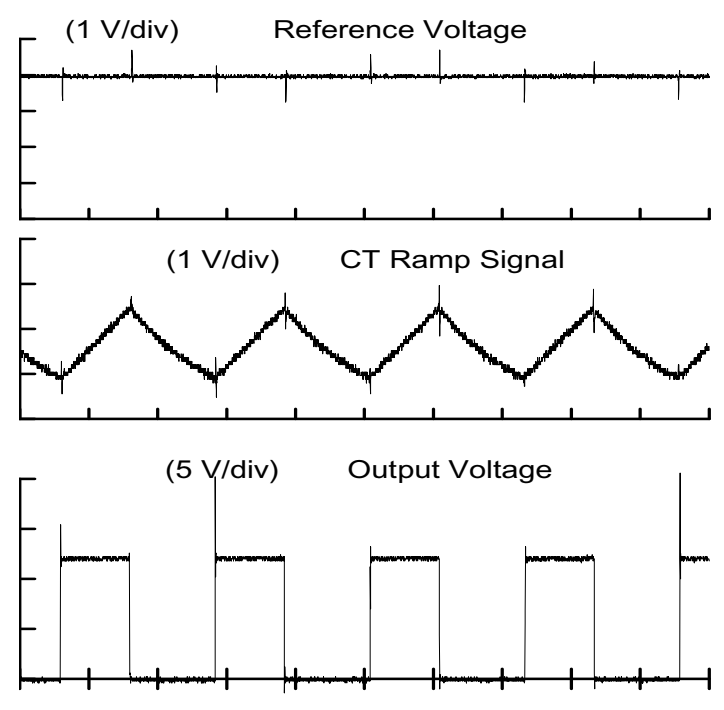

Time (10 us/div)

(a) Temperature $=25^{\circ} \mathrm{C}$

Figure 4. Waveforms of PWM Controller at $25{ }^{\circ} \mathrm{C}$.

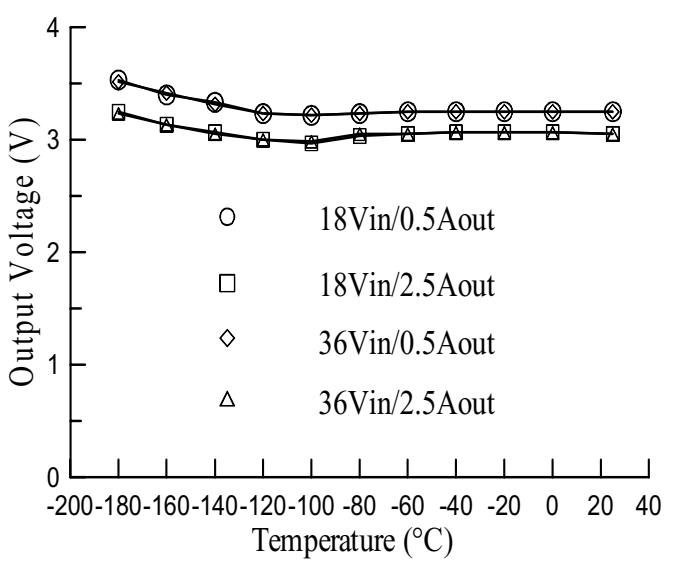

Figure 3. Superior performance of another commercial dc/dc converter.
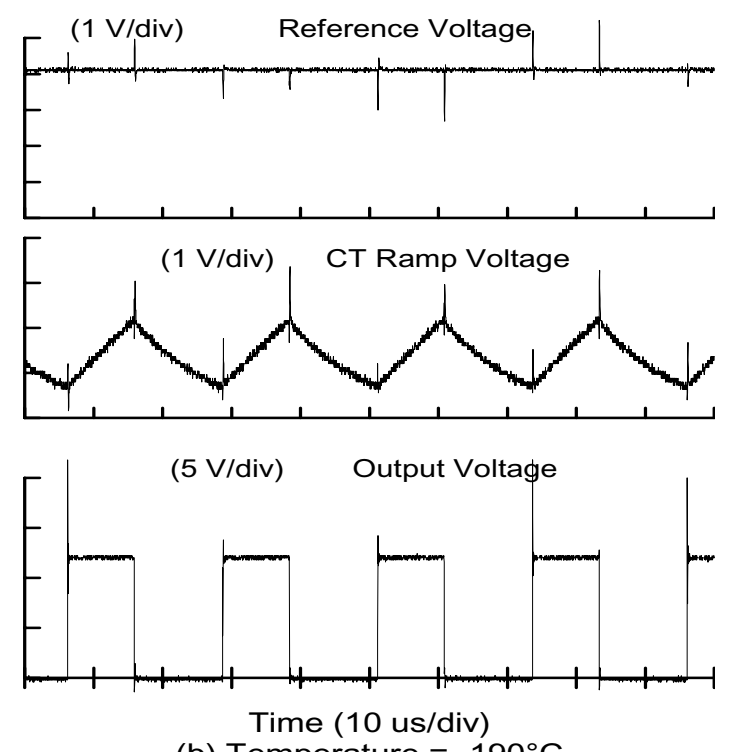

(b) Temperature $=-190^{\circ} \mathrm{C}$

Figure 5. Waveforms of PWM Controller at $-190{ }^{\circ} \mathrm{C}$. 


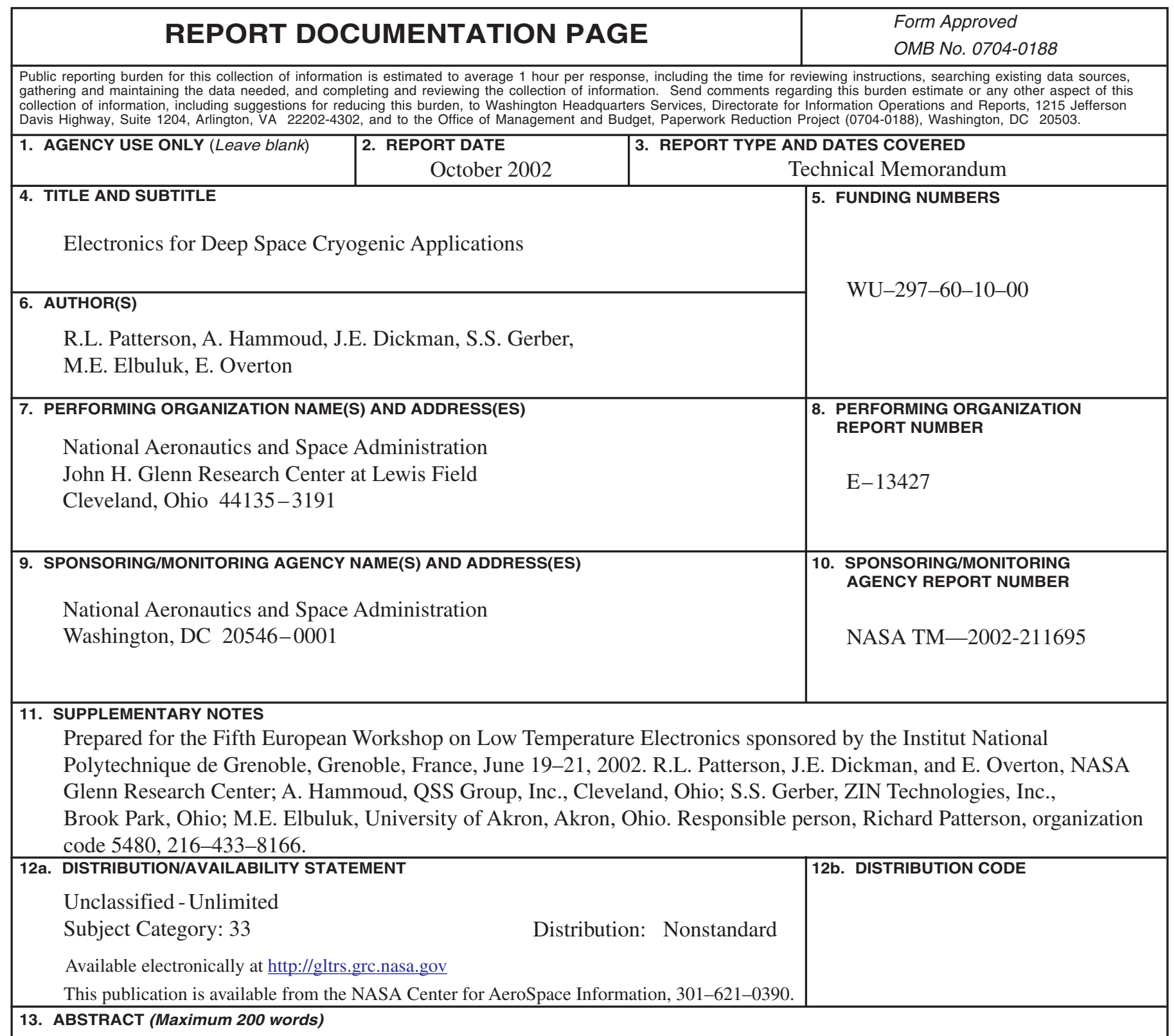

Deep space probes and planetary exploration missions require electrical power management and control systems that are capable of efficient and reliable operation in very cold temperature environments. Typically, in deep space probes, heating elements are used to keep the spacecraft electronics near room temperature. The utilization of power electronics designed for and operated at low temperature will contribute to increasing efficiency and improving reliability of space power systems. At NASA Glenn Research Center, commercial-off-the-shelf devices as well as developed components are being investigated for potential use at low temperatures. These devices include semiconductor switching devices, magnetics, and capacitors. Integrated circuits such as digital-to-analog and analog-to-digital converters, DC/DC converters, operational amplifiers, and oscillators are also being evaluated. In this paper, results will be presented for selected analog-to-digital converters, oscillators, DC/DC converters, and pulse width modulation (PWM) controllers.

14. SUBJECT TERMS

Cryogenic; Power; Electrical; Electronics; Space

\begin{tabular}{|c|c|c|}
\hline $\begin{array}{c}\text { 17. SECURITY CLASSIFICATION } \\
\text { OF REPORT } \\
\text { Unclassified }\end{array}$ & $\begin{array}{c}\text { 18. SECURITY CLASSIFICATION } \\
\text { OF THIS PAGE } \\
\text { Unclassified }\end{array}$ & $\begin{array}{c}\text { 19. SECURITY CLASSIFICATION } \\
\text { OF ABSTRACT } \\
\text { Unclassified }\end{array}$ \\
\hline
\end{tabular}

NSN 7540-01-280-5500

Standard Form 298 (Rev. 2-89) Prescribed by ANSI Std. Z39-18
$298-102$ 